\title{
Corrosion of Aluminum Clad Spent
}

Nuclear Fuel in the 70 Ton Cask during

Transfer from L Area to H-Canyon

\section{J. I. Mickalonis}

June 2014

SRNL-STT-2014-00232, Revision 0 
SRNL-STI-2014-00232

Revision 0

\section{DISCLAIMER}

This work was prepared under an agreement with and funded by the U.S. Government. Neither the U.S. Government or its employees, nor any of its contractors, subcontractors or their employees, makes any express or implied:

1. warranty or assumes any legal liability for the accuracy, completeness, or for the use or results of such use of any information, product, or process disclosed; or

2. representation that such use or results of such use would not infringe privately owned rights; or

3. endorsement or recommendation of any specifically identified commercial product, process, or service.

Any views and opinions of authors expressed in this work do not necessarily state or reflect those of the United States Government, or its contractors, or subcontractors.

\section{Printed in the United States of America \\ Prepared for \\ U.S. Department of Energy}


Keywords: Aluminum cladding, corrosion loss, elevated temperature

Retention: Permanent

\title{
Corrosion of Aluminum Clad Spent Nuclear Fuel in the $\mathbf{7 0}$ Ton Cask during Transfer from $\mathrm{L}$ Area to $\mathrm{H}$-Canyon
}

\author{
J. I. Mickalonis
}

June 2014

Prepared for the U.S. Department of Energy under contract number DE-AC09-08SR22470. 


\section{EXECUTIVE SUMMARY}

Aluminum-clad spent nuclear fuel will be transported for processing in the 70-ton nuclear fuel element cask from L Basin to H-canyon. During transport these fuels would be expected to experience high temperature aqueous corrosion from the residual L Basin water that will be present in the cask. Cladding corrosion losses during transport were calculated for material test reactor (MTR) and high flux isotope reactors (HFIR) fuels using literature and site information on aqueous corrosion at a range of time/temperature conditions. Calculations of the cladding corrosion loss were based on Arrhenius relationships developed for aluminum alloys typical of cladding material with the primary assumption that an adherent passive film does not form to retard the initial corrosion rate. For MTR fuels a cladding thickness loss of $33 \%$ was found after 1 year in the cask with a maximum temperature of $260{ }^{\circ} \mathrm{C}$. HFIR fuels showed a thickness loss of only $6 \%$ after 1 year at a maximum temperature of $180{ }^{\circ} \mathrm{C}$. These losses are not expected to impact the overall confinement function of the aluminum cladding. 


\section{TABLE OF CONTENTS}

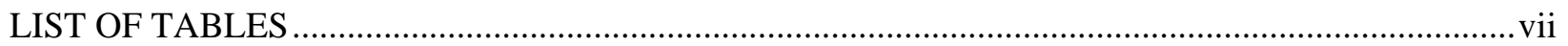

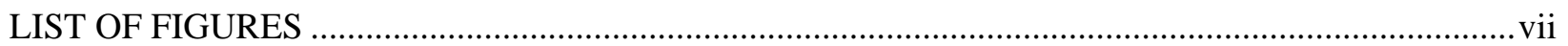

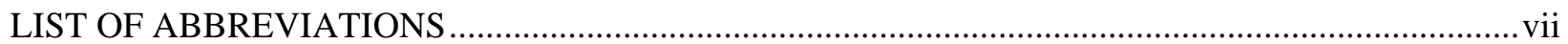

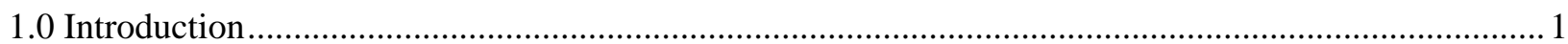

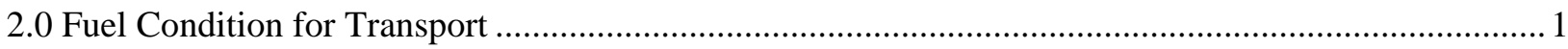

3.0 High Temperature Aqueous Corrosion of Aluminum Cladding ....................................................... 2

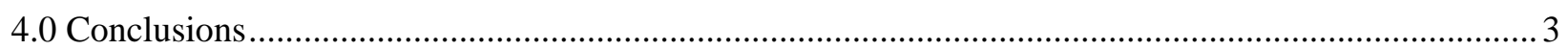

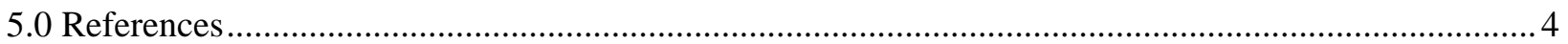




\section{LIST OF TABLES}

Table 1. Parameters for Transport of Spent Nuclear Fuel Pertinent to Corrosion Assessment. 2

\section{LIST OF FIGURES}

Figure 1. Aluminum cladding losses calculated from Arrhenius rate expression developed by Hilton ....... 3

\section{LIST OF ABBREVIATIONS}

$\begin{array}{ll}\text { HFIR } & \text { High flux isotope reactor } \\ \text { MTR } & \text { Material test reactor } \\ \text { SRNL } & \text { Savannah River National Laboratory } \\ \text { SNF } & \text { Spent nuclear fuel }\end{array}$




\subsection{Introduction}

Aluminum-clad spent nuclear fuel (SNF) will be transported for processing in the 70-ton nuclear fuel element cask from L Basin to H-canyon. During transport these fuels would be expected to experience high temperature aqueous corrosion from the residual L Basin water that will be present in the cask. Therefore, the aluminum cladding will experience a loss of thickness during transport. Since the cladding is needed on the fuel elements to maintain confinement of radionuclides (i.e. maintaining fuel cladding configuration), an evaluation was performed to estimate the corrosion of the aluminum cladding for the SNF in L Basin.

An evaluation was performed previously for Material Test Reactor (MTR) design fuel, which were bounded by the Missouri University Research Reactor and/or High Flux Beam Reactor fuels [1]. The current evaluation was performed for fuel elements for the High Flux Isotope Reactor (HFIR). This document incorporates the previous evaluation for the MTR fuel with that of the HFIR fuel.

\subsection{Fuel Condition for Transport}

The shipment of the MTR and HFIR fuels differ in their spatial arrangement, heat flux, and maximum temperature [2-4]. These fuels can be characterized as a dispersion of uranium compounds in an aluminum matrix. The fuel elements are clad with one of the aluminum alloys 1100, 5052, or 6061 or their foreign equivalents. The fuel matrix and cladding maintain a metallurgical bond even after irradiation (i.e. maintaining fuel cladding configuration).

The MTR fuels typically consist of aluminum clad uranium aluminide (UAl) or aluminum-uranium oxide $\left(\mathrm{Al}-\mathrm{U}_{3} \mathrm{O}_{8}\right)$, which is formed as a flat or curved plate or other similarly formed fuel (a nested cylindrical configuration). The aluminum cladding is typically 15 mils thick. For handling, the MTR fuels are bundled in aluminum tubes (6061 or 6063), that are either General Purpose tubes or L Bundles. The tubes would only be nominally drained and not dried prior to transport. Water, at a depth of up to 4 inches, is assumed to remain in the cask following draining after removal from L-Basin. This amount of water is still not sufficient to contact the fuel elements. The cask may contain between 9 to 12 tubes, each containing up to 4 MTR fuel assemblies. The actual number of tubes is driven by the loading requirement which maintains a fuel temperature that does not exceed $260{ }^{\circ} \mathrm{C}$ [4].

The HFIR fuel consists of two nested fuel elements. The fuel plates within each element are composed of aluminum-clad $\mathrm{Al}-\mathrm{U}_{3} \mathrm{O}_{8}$. The aluminum cladding has a 12 mil thickness. For storage and transport, each HFIR inner or outer fuel element is placed on an inner or outer aluminum carrier for handling. The carrier remains with the fuel during transport in the cask. The fuel elements are placed on the HFIR cask insert which is designed to hold up to eight fuel elements (alternating inner and outer). Some residual water will be in the cask from the draining of the fuel elements but still not sufficient to contact the fuel elements on the insert. The maximum fuel temperature will be $180{ }^{\circ} \mathrm{C}$ for 4 inner HFIR elements and 4 outer HFIR elements [4].

The cladding thickness is reduced by corrosion during reactor operation. Boehmite $\left(\mathrm{A}_{2} \mathrm{O}_{3} \cdot \mathrm{H}_{2} \mathrm{O}\right)$, an aluminum oxyhydroxide, grows on the aluminum cladding with typically oxide thickness ranging from 20 to $50 \mu \mathrm{m}$ [17]. A corresponding metal loss is $23 \mu \mathrm{m}$ or approximately $1 \mathrm{mil}$ from the formation of this boehmite layer. Since the SNF is stored in L-basin after delivery to the site, general corrosion of the aluminum cladding may occur. ${ }^{1}$ This loss of cladding thickness is expected to be insignificant due to the

\footnotetext{
${ }^{1}$ Pitting corrosion also occurs during storage and will breach the cladding but not impact overall thickness. In 1998, it was estimated that approximately $2 \%$ of foreign and domestic research reactor fuels have cladding breaches (excluding Australia, Brazil and Thailand which had poor storage requirements) after cooling times in basins that vary from 1 to 20 years [18]. These fuels are presently stored directly in L-Basin.
} 
thick boehmite oxide layer that resulted during reactor operation. The post-operation, post-storage cladding thickness is assumed to be 11 and $14 \mu \mathrm{m}$ for the HFIR and MTR fuels, respectively.

Table 1 summarizes the data for each fuel type that is pertinent to the corrosion assessment of the cladding for transport between L- and H-areas.

Table 1 Parameters for Transport of Spent Nuclear Fuel Pertinent to Corrosion Assessment

\begin{tabular}{|l|c|c|}
\hline \multicolumn{1}{|c|}{ Condition } & HFIR & MTR \\
\hline Number of elements & 8 & $36-48$ \\
\hline Maximum temperature $\left({ }^{\circ} \mathrm{C}\right)$ & 140 & 260 \\
\hline Initial cladding thickness (mils) & 12 & 15 \\
\hline $\begin{array}{l}\text { Post-operation, post-storage } \\
\text { cladding thickness (mils) }\end{array}$ & 11 & 14 \\
\hline
\end{tabular}

\subsection{High Temperature Aqueous Corrosion of Aluminum Cladding}

In the 70-ton cask during transport, water is present on the aluminum cladding surface as a residual or adsorbed layer and as water vapor due to the elevated temperature from decay heat. General corrosion of aluminum in a saturated water vapor environment and in water is similar. General attack is the predominant corrosion mode at high temperatures as observed in vapor corrosion tests at SRNL [5]. Even in the presence of pits through the cladding, aluminum oxidation or corrosion is expected to be preferential over that of the fuel meat. Surface characterization of $\mathrm{Al}-\mathrm{UAl}_{\mathrm{x}}$ specimens reacted with saturated water vapor revealed a uniform corrosion layer of hydrated aluminum oxide, similar to that observed on aluminum, with no indication of localized attack [6]. At temperatures above $80^{\circ} \mathrm{C}$, aluminum forms boehmite as the hydrated aluminum oxide. Similarly for Al- $\mathrm{U}_{3} \mathrm{O}_{8}$, the corrosion behavior was considered the same as that of the aluminum matrix, since the reaction rate of $\mathrm{U}_{3} \mathrm{O}_{8}$ with water is very small by comparison [7].

Hilton from Argonne National Laboratory evaluated SNF oxidation data [6]. The oxidation rate data in his report were from literature data [5, 7-16] and were limited to pure oxygen and water environments with low conductivity and negligible impurity levels, which would represent baseline corrosion kinetics and be representative of corrosion in L Basin water. Hilton developed Arrhenius equations for both aluminum and aluminum-matrix uranium aluminide dispersions and uranium silicides. The Arrhenius corrosion rate equation for aluminum, which was determined from a regression analysis $(\mathrm{R}=0.95)$ of data for aluminum alloys 6061 and 8001 is:

$$
\mathrm{K}=4.29\{\exp ((-32.8 \pm 1.8 \mathrm{~kJ} / \mathrm{Mole}) / \mathrm{RT})\} \quad(\mathrm{mg} \text { metal lost/cm2/hr) }
$$

(Equation 1)

where $\mathrm{R}$ is the gas constant and $\mathrm{T}$ is the temperature $\left({ }^{\circ} \mathrm{K}\right)$. The applicable temperature range of the rate expression is 25 to $360{ }^{\circ} \mathrm{C}$. Equation 1 provides general corrosion rates for water and saturated water vapor and is conservative since no passivation or oxide file growth is assumed. Data used in developing this equation above $100^{\circ} \mathrm{C}$ was from coupons placed in autoclave systems, although high pressures will not develop in the cask since it is vented.

Using the rate expression, corrosion losses to the cladding were calculated for times up to one year over the temperature range of 100 to $300{ }^{\circ} \mathrm{C}$. An aluminum density of $2.7 \mathrm{mg} / \mathrm{cm}^{3}$ was used for these calculations. Figure 1 shows the results of these calculations as a plot of cladding loss (mils) versus time (hours). The expected time of exposure of the fuels in the 70-ton cask is not anticipated to be extended beyond a couple of months. Conservative extended times were evaluated to assess the impact on the cladding thickness. For the MTR fuels, a maximum temperature of $263{ }^{\circ} \mathrm{C}$ was determined from a heat 
load of 2,750 watts [4]. As seen in the figure, the MTR fuels would experience cladding thickness losses of approximately 2.5 and 5 mils after storage in the cask for 6 months and 1 year, respectively. For the HFIR fuels, the loading requirement for a maximum fuel temperature is $180{ }^{\circ} \mathrm{C}$. The cladding thickness loss at 6 months and 1 year for HFIR fuel would be 0.3 and 0.7 mils, respectively.

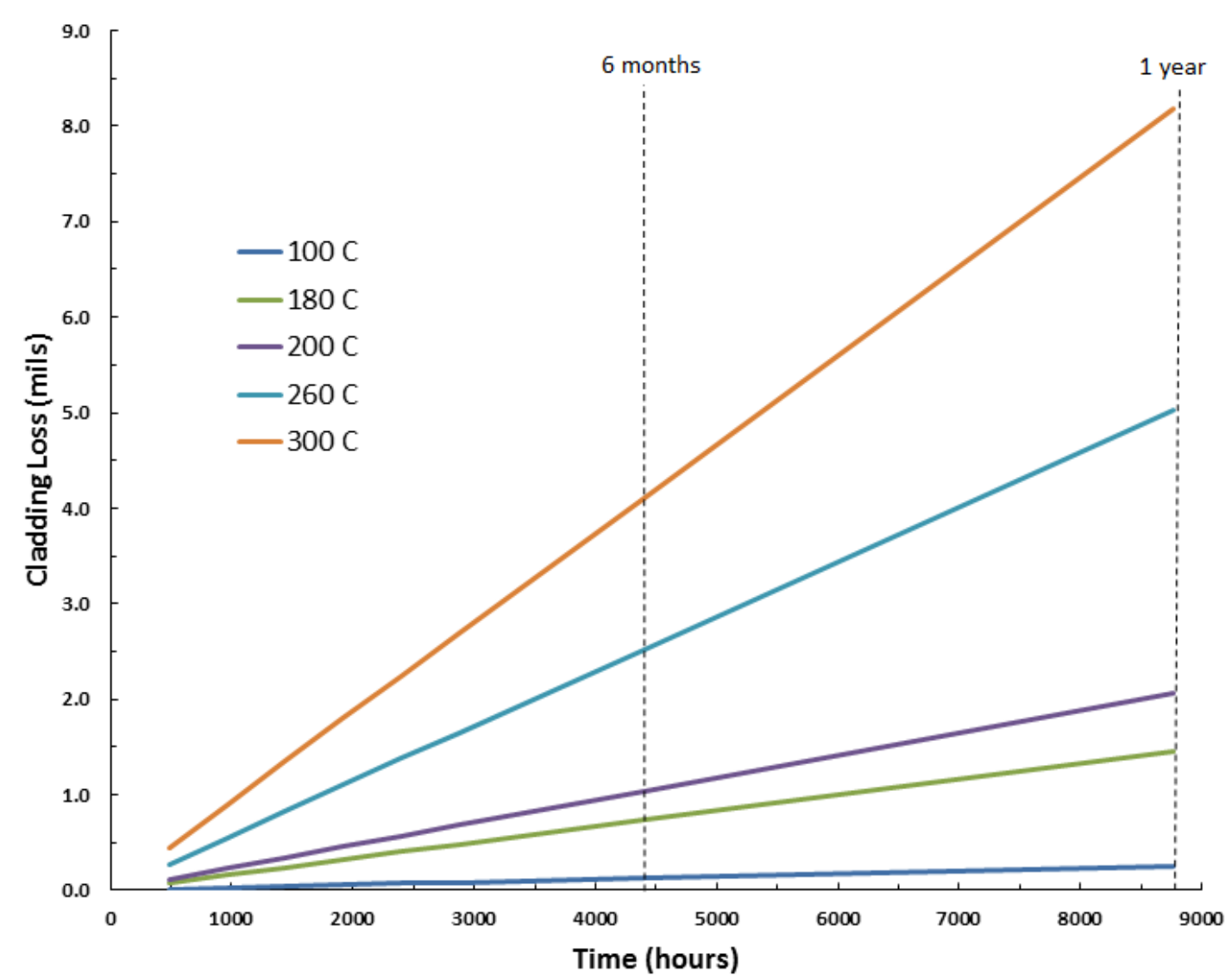

Figure 1 Aluminum cladding losses calculated from Arrhenius rate expression developed by Hilton [6]

From an experimental study by Lam et al, high Mg content aluminum (5XXX series) cladding alloys were found to be subject to aggressive "break-away" corrosion behavior [5]. This phenomenon, if it would occur, may challenge the cladding confinement function for these alloys in a high temperature vapor environment for extended exposures. For this reason, it is recommended that fuel should not be stored in a configuration where it is exposed to high temperature water vapor for more than 120 days.

Since the fuel has been stored in water for variable lengths of time, pitting corrosion may have occurred and led to possible breaches. These breaches are expected to be minor in L Basin fuel since the water chemistry is well controlled, which would minimize corrosion. These minor breaches have been previously evaluated for impact on containment during shipping and found to be negligible [18].

In general the cladding confinement function will not be compromised for either the MTR or HFIR fuel after up to one year of storage in the 70 -ton cask. The MTR fuel will see a loss of $33 \%$ of cladding thickness while the HFIR fuel would only experience a loss of approximately $6 \%$ from original thickness. These losses would be conservative since the no oxide is assumed to form, which would passivate the aluminum and slow any additional corrosion. 


\subsection{Conclusions}

Corrosion loss calculations were performed for aluminum-clad spent nuclear fuels to assess the impact during transport from L Basin to H-canyon in a 70-ton nuclear fuel element cask. These calculations were based on Arrhenius relationships developed for aluminum alloys typical of cladding material. For MTR fuels a cladding thickness loss of $33 \%$ was found after 1 year in the cask. HFIR fuels showed a thickness loss of only 6\%. These losses are not expected to impact the overall confinement function of the aluminum cladding.

\subsection{References}

1. P. R. Vormelker, inter-office memorandum to M. W. Loibl, "Corrosion of Aluminum Clad Spent Nuclear Fuel in the 70 Ton Cask during Shipment from L-Area to H-Canyon,” SRNL-L7200-20100013, May 10, 2010

2. D. F. Gehr, II and J. A. Schlesser, "Nuclear Criticality Safety Evaluation: Safe Onsite Transport of 70-Ton Cask,” N-NCS-G-00133, Revision 7, April 2012

3. S. T. Gough, "Nuclear Criticality Safety Evaluation: HFIR Fuel in 70-Ton Cask,” N-NCS-G-00071, Revision 0, March 2001

4. S. Y. Lee, "Thermal Analysis for the SRS 70 Ton Cask," M-CLC-A-00386, Revision 4, June 2014

5. P. S. Lam, R. L. Sindelar, H. B Peacock, "Vapor Corrosion of Aluminum Cladding Alloys and Aluminum-Uranium Fuel Materials in Storage Environments,” WSRC-TR-97-0120, April 1997

6. B. A. Hilton, "Review of Oxidation Rates of DOE Spent Nuclear Fuel: Part 1: Metallic Fuel," ANL-00/24, Argonne National Laboratory, Idaho Falls, ID, November 2000

7. H. B. Peacock and R. L. Frontroth, "Properties of Aluminum-Uranium Alloys”, WSRC-RP-89-489, 1989

8. F. L. LaQue and H. R. Copson, Corrosion Resistance of Metals and Alloys, $2^{\text {nd }}$ ed., Reinhold Publishing Corporation: New York, 1963

9. J. E. Draley et al, "High Temperature Aqueous Corrosion of Aluminum Alloys," Proceedings of Second International Conference on the Peaceful Uses of Atomic Energy, Properties of Reactor Materials, Geneva, P/114, Vol. 5, pp 113-120, United Nations, New York, 1958

10. J. E. Draley and W. E. Ruther, "Corrosion of Aluminum Alloys by Flowing High Temperature Water,” ANL-7227, Argonne National Laboratory: Argonne, IL, 1967

11. C. R. Breden and N. R. Grant, "Summary of Corrosion Investigations on High Temperature Aluminum Alloys,” ANL-5546, Argonne National Laboratory, Argonne, IL, 1969

12. N. R. Grant, "Summary of Corrosion Investigations of High-Temperature Aluminum Alloys," ANL-6204, Argonne National Laboratory: Argonne, IL., 1961

13. S. Aas and K. Videm, "Improved Aluminum Alloys as Fuel Cladding Material in Water-Cooled Power Reactors," Proceedings of the Third International Conference on the Peaceful Uses of Atomic Energy, United Nations: Geneva, 1965

14. J. A. Ayers, R. L. Dillon, and R. J. Lobsinger, "The Use of Aluminum as Fuel Cladding in Pressurized Water Power Reactors," Proceedings of the Second International Conference on the Peaceful Uses of Atomic Energy, United Nations: Geneva, 1958

15. A. B. Johnson, "Bases for Extrapolating Materials Durability in Fuel Storage Pools," Proceedings of the Topical DOE Spent Nuclear Fuel-Challenges and Initiatives, American Nuclear Society: Salt Lake City, UT, pp. 83-88, 1994

16. P. S. Lam, R. L. Sindelar, K. Y. Barrett, "Corrosion of Aluminum-Uranium Alloys in Water Vapor at $200^{\circ} \mathrm{C}$,” WSRC-MS-98-00858, 1998

17. K. Ferrel, "Performance of Aluminum Research Reactors," Comprehensive Nuclear Materials, Vol. 5, pp 143-175, 2012

18. D. W. Vinson and P. S. Blanton, "Preliminary Report: Bases for Containment Analyses of Transportation of Aluminum-based Spent Nuclear Fuel, WSRC-TR-98-00317, October 1998 